\title{
Fish in Battle? Quintus of Smyrna and the Halieutica of Oppian
}

\author{
EMILY KNEEBONE
}

\author{
when would the sails drop \\ from my eyes, when would I not hear the Trojan War \\ in two fishermen cursing? \\ (Walcott, Omeros)
}

If Walcott's twentieth-century Omeros recasts the figures of the Trojan War as fishermen, Quintus of Smyrna's Posthomerica features two battle-heroes compared in detail to fishermen spearing fish. Quintus has long been both loathed and admired for the similes of his fourteen-book epic - even critics far from effusive about this "schlechteste Dichter des Altertums", ${ }^{1}$ often accord him some merit in his similes, which are certainly varied and prodigious. ${ }^{2}$ Yet all too often his similes are labelled inappropriate, or dismissed as hackneyed and derivative. ${ }^{3}$ This paper focuses on one of Quintus' more unusual similes, that of Neoptolemus as a night-fisherman (Q.S. 7.569-575). Looking first at the importance of Neoptolemus as the son of Achilles, heir to his father's greatness and newcomer to this war, the simile is then read through the lens of Oppian's Halieutica, that

1 Schmidt (1999), not a statement but a question.

2 James (2004) XXV-XXVI counts 222 similes in the Posthomerica, a total far greater than that of the Iliad, Odyssey or Argonautica, and matched in relative frequency only by Oppian's Halieutica. Way (1913) deemed Quintus' similes important enough to be appended in a catalogue at the end of his Loeb edition of the text, and on similes as roses amongst the Posthomerica's thorns see Müller / Donaldson (1858) vol. 3, 366: "In this painstaking work Quintus has earned the praise of careful versification, and of a certain amount of ingenuity in his similes." Paley (1876) 9 is more generous: "Many of them [sc. Quintus' similes] are of the finest and most felicitous description."

3 Paschal (1904) 38-39, for instance, devises a misguided taxonomy under which Quintus' similes are divided into the imitative and the original, the "fresh" and the "artificial". Combellack (1968) 18 speaks of "Quintus' most atrocious simile", his legion of "inappropriate similes" and the "evil inspiration" (14) which led the poet to make inopportune comparisons: "we sometimes have a feeling that [Quintus] must have proceeded on the principle that if only he puts enough similes into a passage his narrative will be properly impressive and he need not worry about other things" (17). Even the more charitable James (2004) XXVI declares that only around 10\% of Quintus" similes can be called "thematically original". 
influential didactic epic on sea-fishing from the second century A.D. Quintus, it will be shown, draws upon a long-standing discourse of fishing as trickery, using the motif to illuminate the world of Troy, and his interplays with Oppian are rich and rewarding. The model of fiery heroism must cede to a new mode of warfare, and the night-fishing of Neoptolemus contrasts with the bloody slaughter of Deiphobus, who is figured at 9.172-177 as a dispatcher of swordfish. Quintus, in the end, uses similes drawn from Oppianic material to foreground important questions about the nature of war, about the ways in which battle should be waged and cities sacked and about what it is to be an epic hero.

Quintus' Neoptolemus, newly arrived from Scyrus, comes in book 7 as a great boon to the fading Achaeans of the Posthomerica. In his fearless destruction of the enemy forces, he is compared to a night-fisherman spearing the fish he has enticed to his boat with light:

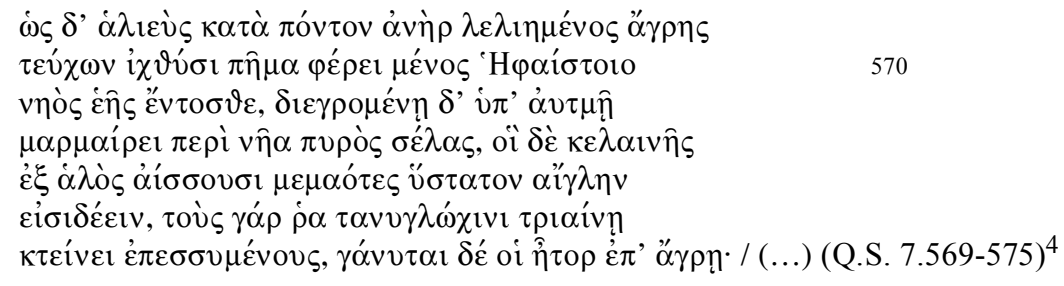

As a fisherman, keen to make a catch at sea,

Carries for the fishes' doom the fire god's power

On board his boat, and when it is kindled by his breath

The fire shines brightly round the boat; from the inky water

The fish come darting, eager for a glimpse of the gleam

That is their last, for with his trident's barbs the fisher

Kills them as they rush up, gladdened by the catch; / (...)

The simile echoes a parallel scene in the Halieutica, Oppian's didactic poem on sea-fishing. Oppian had noted the three types of fishing (with trident, net and hook, a triad to which Quintus will later refer) before turning to the crepuscular fisherman:

(...) $\tau$ ) 640

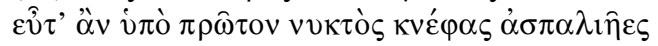

$4 \quad$ Posthomerica: text Vian (1963; 1966; 1969); trans. James (2004). 


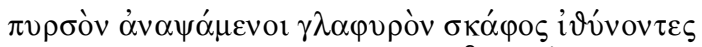

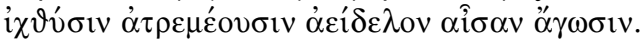

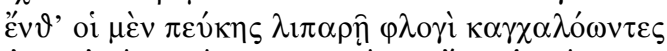

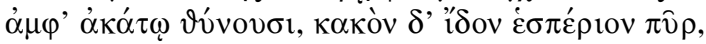

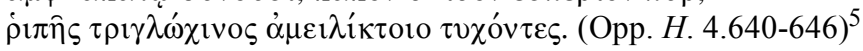

645

(...) but other [fish] evening takes and slays, when at earliest dusk of night with lighted torch the fishers steer their hollow boat, bringing to the resting fishes a darkling doom. Then do the fishes exulting in the oily flame of pine rush about the boat and, to their sorrow seeing the fire at even, meet the stern blow of the trident.

The thematic parallels are clear: a contrast between darkness and light, the lure of fire, the fishes' joy and the mighty trident. Vian even declares that Quintus "s'est contenté de transcrire ce passage sur le mode épique". 6 Yet what place should fish and fishing have on the epic battlefield? Oppian's Halieutica, a five-book fish poem dedicated to the emperor Marcus Aurelius, might at first be thought of little relevance to a narrative depicting the fall of Troy. After all, fishing is a peacetime activity far removed from the plains of Troy; fish themselves are savage creatures belonging to the peculiar and hostile sea, and are notoriously eschewed by Homer's heroes as a source of food. ${ }^{7}$ As James puts it, "Quintus adapts material that is germane to Oppian's subject but purely incidental in the Trojan Epic". 8

Why, then? In the first place, book 7 of the Posthomerica is the point at which Neoptolemus must prove himself, both to the Greeks (and Trojans) and to the readers of the epic, who would necessarily have approached the work from the backdrop of a (cultural, literary and artistic) tradition less than charitable towards Neoptolemus. ${ }^{9}$ This is to be a probationary period for Neoptolemus, and it is significant that the Greek army does not formally welcome him until the end of the book, after he has proven his prowess on the battlefield. Quintus' Neoptolemus is a man to be respected, a man of word and deed and who even in this book displays a touching combination of dignity, diplomacy and modesty following his spectacular success on the battlefield. ${ }^{10} \mathrm{He}$ is a man of nuanced character and

$5 \quad$ Halieutica: text Fajen (1999); trans. Mair (1928).

6 Vian (1954) 50.

7 On the sea as archetypal place of otherness, see Romm (1992); Purcell (1995) 132. The lack of Homeric fish-eating was a puzzling topic, much debated even in antiquity, and which raged furiously in classical scholarship of the early twentieth century. See Combellack (1953), as well as the arguments of Scott (1917), Radin (1922) and the more anecdotal Sanford (1953). More recent studies have focused on the absence of fish from the rituals of public sacrifice in classical Athens: see Wilkins (1993) 192 and Davidson (1997) 13.

8 James (2004) XIX.

9 The cruelty of Neoptolemus was proverbial. See Boyten, this volume.

10 This is a Neoptolemus closer to that of Sophocles' Philoctetes than to the brute we see elsewhere in the tradition. Note that Quintus never dramatises Neoptolemus' unedifying murder of Astyanax, for instance, even if we are witness to the killing of Priam and Polyxena. 
firm morals, of battle-prowess married with diplomacy; his greatest 'flaw' seems to be an excess sensitivity in mourning his father's death.

Having heard so much of the son of Achilles, we finally meet him in person, and he emerges as a young man destined never again to see his father alive, valiant, yet standing in the great man's shadow. In this epic Neoptolemus will become something of a second Achilles, pre-eminent in strength and greatness, and cast in his father's heroic mould. Hera's bitter rebuke to Apollo after Achilles' death had extolled the latter's virtues and divine stock (3.117: $\dot{\varepsilon} \xi \dot{\eta} \mu \dot{\varepsilon} \omega \mathrm{v}$

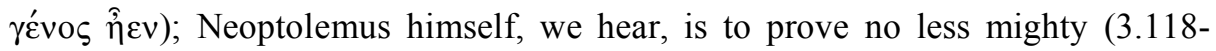
122). Neoptolemus, as Odysseus remarks, is the very image, or عî̉os, of his

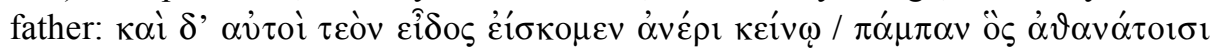

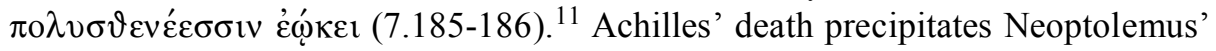
arrival, and the one steps swiftly into the other's shoes. ${ }^{12}$ Neoptolemus even wears his father's famous arms, given to him by Odysseus a hundred lines before. In his father's armour, Neoptolemus becomes a surrogate Achilles, ${ }^{13}$ and not for nothing will the Trojans freeze in terror on seeing Neoptolemus in his father's arms, assuming their bearer to be Achilles himself. ${ }^{14}$ An arming scene, replete with symbolism, draws attention to the likeness:

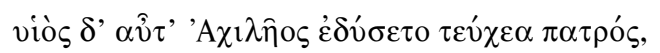

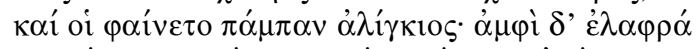
445

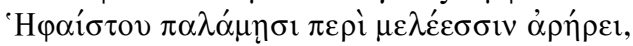

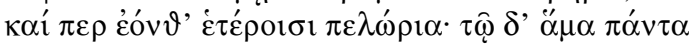

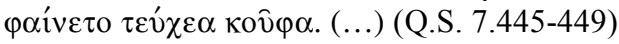

The son of Achilles put on the armor of his father, 445

Which made him look exactly like him. Very lightly, Because of Hephaistos' handiwork, it fitted his frame, Though others would have found it enormous. But to him The armor all seemed light. (...)

11 "We ourselves can see that you are the perfect image / Of that man who rivaled the strength of the immortals." Cf. 7.176-177, 294.

12 Even in structural terms the role of Neoptolemus is thrown into prominence by his arrival from Scyrus after the Ajax-Odysseus dispute but before the arrival of Philoctetes. This allows him to single-handedly save the Achaean day and, as James (2004) XIII / 301 points out, marks a departure from the version of the tale known from the Little Iliad.

13 A fact of which Neoptolemus is all too keenly aware. At 7.665-666, Nestor sets up a simple equation: Neoptolemus is to Eurypylus as Achilles was to Telephus. Hearing this, Neoptolemus

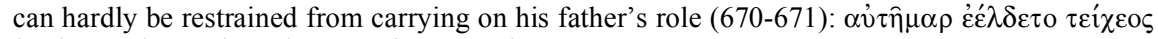

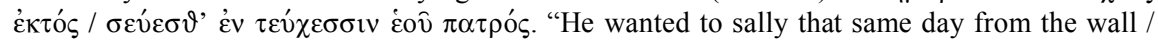
Wearing the armor of his father."

14 7.537-539; cf. Patroclus at Il. 16.278-283. 
If $\varepsilon \dot{ } \pi \tau \tau^{\prime} \lambda \varepsilon \mu \circ \varsigma$ Achilles (mighty warrior, 7.576) was the hero of the Iliad, of the

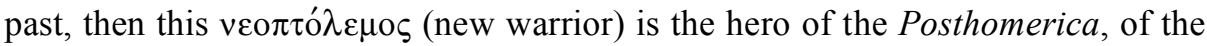
here and now. ${ }^{15}$ Quintus gives us a Neoptolemus 'new' not only in his role as the (in every sense) latest post-Achillean hero, but also in relation to the denigratory literary and artistic tradition in which Neoptolemus was figured as callous brute. Here is a vision of Quintus' own literary ambition, of the ease with which he envisages himself taking up the armoury of Homeric poetics; it hardly needs a Bloom to articulate the significance of the son striding into his father's (literary or martial) boots. If Achilles' shield in book 5 can be read as a mise-en-abime for a specifically Posthomeric Quintean poetics, ${ }^{16}$ then this easy donning of a heavy burden is a further manifestation of Quintus' poetic programme. His is the text which models itself after Father Homer, which arrives, like Neoptolemus to Troy, when that father has passed away, leaving only memories, $\kappa \lambda \dot{\varepsilon} \circ \varsigma$ (glory), and a set of exacting standards. Quintus must establish himself as both like and unlike his 'father', and he sketches a war which both develops and diverges from its predecessor. His is a different age and a different kind of epic warfare; his Neoptolemus must also be figured anew.

Achilles in the Posthomerica suffers no deficit of quasi-Homeric similes. Within the first hundred lines of the hero's appearance in the Posthomerica, for instance, Achilles is compared to a lion (1.524-527), forest fire (1.536-537), wild beast (1.539), hunter (1.543-544), rock (1.549) and hawk (1.572). When Neoptolemus enters battle, half-way through the epic, he is likened to a charging lion (7.464-471), to a herdsman and his dogs driving lions away (7.486-492), and finally to a fisherman using light to draw in fish at night (7.569-575). This last image seems to point to something beyond the Homeric or Achillean lion. For if the Quintean Achilles is more brutish than his Iliadic predecessor, Neoptolemus as fisherman becomes a trickster, a figure who displays both intelligence and courage and who relies on a combination of the two to outdo his opponents. ${ }^{17}$ It is in relation to this inequality that the fishing motif comes to the fore, for the very $\tau \varepsilon^{\prime} \chi \vee \eta$ (craft) of fishing is founded upon a sense of intellectual disparity and the gulf between man and beast. ${ }^{18}$ A mountain lion is perhaps mightier than his

15 Quintus never speaks of "Pyrrhus", a popular moniker for Neoptolemus by this time; his hero is instead a determinedly belated $\underline{\text { Neo-ptolemus. }}$

16 Baumbach, Maciver, this volume.

17 Significantly, the fisherman simile stands immediately after the arrival of Athena to Troy, as she descends to oversee the battle and aid the Achaeans (7.556-563). The goddess' own domains, wisdom and war, are brought together in this image of the wily warrior.

18 This lack of reciprocity lies behind the fishing trope's literary popularity. 'Erotic fishing', 'fishing for a dinner-invitation', 'hooking a gull', 'fishing for old men's wills': all are metaphors based on the inequality of the parties involved. See e.g. Hor. Sat. 2.5; Juv. 4; Mart. 5.63; Lucian Pisc., Merc.Cond. 
victim, yet the pair are still both beasts; the elements impress through sheer force and might, yet these are all contests of strength. Even a hunter must sweat and toil in strength to outdo his prey. The fisherman, however, barely has to exert himself for the fish to offer themselves up, for this is a contest of wits, and his very effortlessness speaks of the gulf between man and these pitiful creatures. Neoptolemus' supremacy over these fish, these Trojans, bodes ill for the fate of Troy.

The fisherman simile forms part of a narratorial assessment of the character of Neoptolemus, then, and reflects upon his role as the glorious son of Achilles (viòs 'A $\chi 1 \lambda \hat{\eta} 0 \varsigma, 7.564,576$ ), an explicitly-foregrounded connection between father and son (cf. 7.564-567). The strength of this genealogical connection is redoubled when we reflect upon Achilles' repeated association through Thetis with the marine realm. If Memnon's maternal connection is with the aether, then Achilles' is naturally with the sea, as Memnon gleefully boasts: $\dot{\eta}$ [sc. Thetis] $\delta$ '

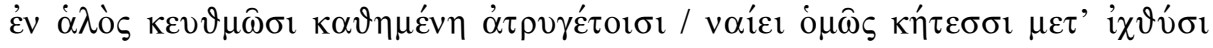
$\kappa v \delta เ o ́ \omega \sigma \alpha(2.426-427) .{ }^{19}$ This association, Poseidon assures us, is no less important for Neoptolemus (9.315-316).

\section{II}

In his simile of Neoptolemus as fisherman, moreover, Quintus draws upon a longstanding epic and didactic connection between warriors, fish and fishermen. Fish play their part in Homeric epic both as ravening predators (aligned with wild dogs and birds) and as prey, particularly in those similes of death and destruction with which the poems abound. Patroclus kills Thestor, Achilles chases Trojans into the Scamander, Iris plummets through the air, Epeius strikes at Euryalus, Scylla and the Laestrygonians devour their victims, Odysseus slays the suitors and Sarpedon delivers a warning to Hector: all are figured in ichthyic terms. ${ }^{20}$ Nor are Quintus' depictions of fish restricted to simile, for we should note that episode in book 11 of the Posthomerica in which Polydamas kills two Greek fishermen:

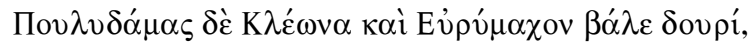

60

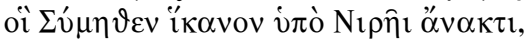

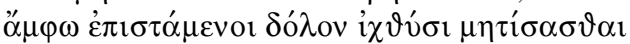

19 "Your mother is hidden in the barren depths of the sea, / Along with the monsters and fish that are her pride and joy." - Note too that upon Achilles' death, the sea resounds with the lamentation of the Nereids (3.582-594).

20 Patroclus: Il. 16.409-413, Achilles: Il. 21.22-24, Iris: Il. 24.80-82, Epeius: Il. 23.692-694, Scylla: Od. 12.251-254, Laestrygonians: $O d$. 10.124, Odysseus: $O d$. 22.384-388 and Sarpedon: Il. 5.487-488. As Scott (1974) 75 points out, in most cases "the fish similes occur in two basic narrative situations: men killed or going to be killed and a warrior or enemy killing". 


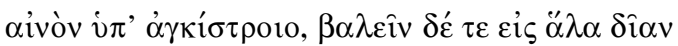

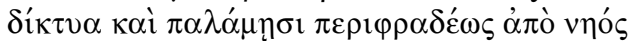

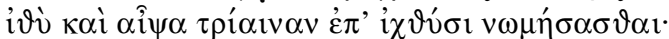

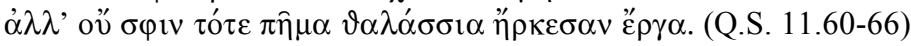

Polydamas' spear struck Kleon and Eurymachos,

Who'd come from Syme under Nireus' command,

Both of them skilled in the art of fatally fooling fish

By means of a hook, of casting nets in the sacred sea,

And of wielding with expert hands from the side of a boat

A trident with straight and speedy aim at the fish.

But all their sea craft failed to save them then from ruin.

The scene is reminiscent of the death of the Trojan warrior Scamandrius in the Iliad, he whose skill in hunting is nevertheless useless in the face of Menelaus' spear (Il. 5.49-54). Yet it is also an Oppianic theme. For immediately before his instructions on fishing at night, Oppian had told of the three methods of catching fish: with hook, net or trident (Opp. H. 4.637-639). In Quintus, these fishermen assume the place of the Homeric huntsman: this is Homer read through Oppian. As with the fish similes in the Posthomerica, however, Quintus draws not upon the astonishing and imaginative array of similes in the Halieutica, but upon Oppian's technical discussion of fishing methods. This might sound reasonable in relation to Aratus and Nicander, whose poetry is rather less rich in simile, but Oppian is remarkable primarily for his extended similes, a style which strongly distinguished him from his didactic predecessors and which probably influenced Quintus' own poetic tendencies. ${ }^{21}$ In the Halieutica Oppian continually inverts the Homeric connection between fish and warrior; his fish are embroiled in quasiIliadic battles, simile after simile painting them as warriors, as citizens besieged or as victims of war. Whilst men at war are in Homer compared to fish, in the Halieutica fish are compared to men at war, directly reversing the epic comparatum and comparandum. ${ }^{22}$ When, for instance, spring comes to the wintry sea, Oppian's fishes rejoice like citizens of a besieged city as the enemy withdraws; ${ }^{23}$

21 Rebuffat (2001) 241-242: “In Oppiano la similitudine ha, per quantità e per qualità, un'importanza incomparabilmente maggiore che negli altri poeti didascalici. [...] le similitudini, più di ogni altra peculiarità, collocano gli Halieutica in un posto particolare nella poesia didascalica greca." For Oppian's influence on Quintus' simile-practice see James (2004) XXV-XXVI.

22 An inversion perhaps familiar from Latin didactic poetry: Virgil's vines, for instance, are figured as soldiers (Georg. 2.372-387), and his drainage-channel likened to Achilles' fight with the Scamander (Georg. 1.104-110). See Schindler (2000a) 162-166, Thomas (1986) 178-179, Spinoula (2000) 65. It is perhaps important that didactic epic was traditionally aligned with, and often termed a subset of, narrative epic, although debate still rages about the importance of such genre-division in antiquity. We might do well simply to note, with Gale (2004) XIII, that "the boundary between epic and didactic is one notoriously subject to border-disputes".

23 Opp. H. 1.463-469. 
when the muraena devours an octopus, she vaunts over him like a Homeric hero, rending him from his rock like a soldier dragging a child from its mother in war. ${ }^{24}$ If, as James has suggested, poets in the Greek didactic tradition had previously tended to eschew the extended simile for fear of trespassing on Homeric territory, then Oppian's simile-practice marks a determined return of his didactic poetry to Homer, to the epic fold. ${ }^{25}$ Yet whilst Quintus' dealings with Apollonius, for instance, are evident in his overt indebtedness to the vocabulary of Apollonian simile, ${ }^{26}$ in the case of Oppian Quintus makes no linguistic distinction between his own turn of phrase and the didactic material of the Halieutica. This, as Vian points out, puts Oppian in a unique position amongst Quintus' literary forebears:

Quand Q.S. puise la matière de ses comparaisons chez ses grands devanciers (Homère, Apollonios, voire Aratos), il n'hésite pas à avouer sa dette et aime s'approprier des expressions ou des formules de l'original. Son comportement est différent vis-à-vis d'Oppien: il ne cherche dans son livre que des sujets qu'il traite ensuite avec son style propre. $^{27}$

For Vian, an explanation lies in the temporal proximity of these works. Oppian is simply too recent a poet to be quoted directly in the Posthomerica; ${ }^{28}$ Quintus "veut peut-être marquer la distance qui sépare une grande œuvre épique d'un traité didactique". ${ }^{29}$ I would posit a different connection, however. Far from marking the distance between epic and didactic, between the Halieutica and the Posthomerica, Quintus quite consciously incorporates the Oppianic sphere into his own martial world, eliding the distance between the acts of fishing and warfare. Quintus delights in the technical detail; ${ }^{30}$ as in the didactic tradition, such detail becomes a weapon in the armoury of epic rhetoric. Quintus' technical details, pace Campbell, must not be read as mere weak attempts at a quasi-

24 Opp. H. 2.305-318.

25 James (1969) 77. Oppian's similes have long been singled out as exceptional, held up beside those of Homer. See e.g. Eust. 3.667.12.

26 See Effe (2005). It is unfortunate that so little post-Homeric, pre-Quintean narrative epic should survive; perhaps we are led to extrapolate unduly from Apollonius.

27 Vian (1954) 51. Cf. James (1970).

28 An argument which Vian takes to substantiate Paschal's claim that the Posthomerica is relatively early in date.

29 Vian (1954) 51.

30 Compare the medical similes of the Posthomerica, whose density of technical description has long been remarked upon. Cf. Ozbek, this volume. Laocoon's divinely-inflicted blindness, for instance, is drawn by Quintus at $12.400-415$ with such attention to physiological symptoms that we are able to recognise the various stages of what would now be termed 'congestive glaucoma'. 
Hellenistic learnedness, but rather as a coalescence of the didactic and the martial in the epic sphere. ${ }^{31}$

Crucially, Quintus' depiction of Cleon and Eurymachus centres upon the essential character of fishing: that of trickery ( $\delta$ ó $\lambda$ o $\varsigma$ or $\mu \hat{\eta} \tau \imath \varsigma)$. This is a notion replayed over and over in the Halieutica, and one which governs the concept of fishing more widely. As Detienne / Vernant have shown, fishing had long been considered insidious and full of trickery, relying upon deception for its very success in hooking a fish. ${ }^{32}$ Fish and fisherman strive to outdo each other in guile; it is no coincidence, for instance, that the word $\delta$ ó $\lambda$ os referred originally to the bait used to catch a fish, and only then to a wider notion of deceit or guileful contrivance. ${ }^{33}$ Plato in his Laws inveighs against fishing (indeed, against the use of nets and traps in general) on the basis that it fosters duplicity and cunning, running counter to the straightforward behaviour of the upright moral citizen. The fisherman is a devious and suspect figure not just in epic but in classical literature more widely. ${ }^{34}$ His trickery, moreover, is often mapped onto a discourse of gender and manliness: fishing, it is said, relies not upon strength but on 'effeminate' guile, ${ }^{35}$ upon that same combination of deviousness and cowardly distance which is so despised by Ajax and Achilles in the 'unheroic' pursuit of archery, and to which we will so often return in this epic. ${ }^{36}$

For all their piscatorial guile, however, Cleon and Eurymachus fall victim to Polydamas' spear; Quintus opposes $\delta$ '́ $\lambda$ o $\varsigma$ and $\mu \hat{\eta} \tau \imath \varsigma$ in the sphere of fishing to a brute physical force which slays these men in war. ${ }^{37}$ A polarity emerges between Bín and $\mu \hat{\eta} \tau \imath \varsigma$, between the martial and the non-martial sphere, and between the force of the spear and the cunning contrivances of the fisherman. Yet what is

31 Campbell (1981) 195: "Q. is a poeta doctus to the extent that he treats Homer very much in the spirit of Apollonius, though obviously on a less rigorous intellectual level." Cf. ibid., 136 n. 79.

32 Detienne / Vernant (1978) 45-46: "As far back as one can trace it, the terminology of mêtis associates it with techniques whose relationship to hunting and fishing is obvious. A mêtis or a dolos is woven, plaited or fitted together [...] just as a net is woven, a weel is plaited or a hunting trap is fitted together."

33 Cf. the $\delta$ ó $\lambda$ os-bait at $O d .12 .252$.

34 Pl. $L g$. 822d-24. In Attic Comedy, fishermen are similarly presented as low-born, weaselling and untrustworthy. See Davidson (1997) passim.

35 Aus. Ep. 4.1.62, 6.1-2 advises Theon to take up fishing or poetry so as not to be scarred by the more vigorous pursuit of hunting. Even Oppian must in book 1 go to some lengths to emphasise the 'heroic' nature of his fishermen, whilst at the same time making much of their duplicity.

36 Cf. Lycus and Amphitryon at Eur. Heracl. 140-235, esp. 160-164. My thanks to Silvio Bär for suggesting this parallel. Quintus' Philoctetes similarly accuses Aeneas of effeminacy, fighting

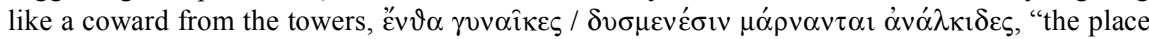
/ Where feeble women fight their foes" (11.492-493).

37 Perhaps it is significant that the pair fall under the command of Nireus, that notoriously beautiful but ineffectual fighter at whose death Eurypylus draws a polarity between strength and beauty (6.385-389; cf. 7.7-12). 
remarkable about the Neoptolemus simile is that it avoids this opposition: the fisherman catches his fish at night by a combination of force and trickery. Neoptolemus, unlike Eurymachus and Cleon, is the fisherman who succeeds also in war, and his success requires both force and guile, Bín and $\mu \hat{\eta} \tau 1 \zeta$. The fisherman's nocturnal deception, the fishes' complacent revelling, the unequivocal destruction which ensues: surely we can see in this scene a connection to the Wooden Horse, that other $\delta$ ó $\lambda$ o for Neoptolemus. ${ }^{38}$ Traditionally, after all, honest deeds (whether fighting or fishing) belong in the daylight hours, for deception rules at night. Immediately after his description of the night-fisherman in the Halieutica, moreover, Oppian describes what is for him an hateful exemplum of piscatorial trickery and moral acceptability: the use of poison to catch fish. This, he declares, is guile gone too far, and his pained depiction of the fishes' torment reflects upon the nature of fishing and the price of victory. The final image of this vignette, and that which starkly ends book 4 , is the simile of a city at war:

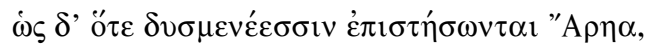
685

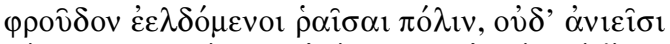

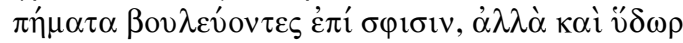

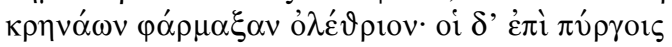

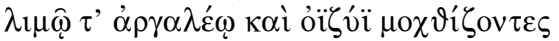

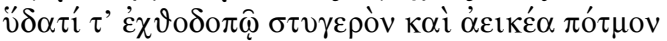

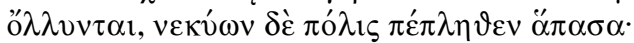

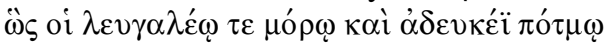

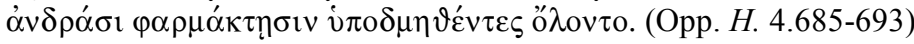

As when men bring war upon their foes, eager to destroy and raze their city, and cease not to devise evil in their hearts but even poison with deadly poison the water of their wells: and the others within their towers, afflicted by grievous hunger and distress and hateful water, perish by a sorrowful and unseemly doom, and the whole city is full of dead; so by a sad death and untoward doom, overcome by the poison of men, the fishes perish.

This is the very limit-case of deception and of the war against fish; such immoral trickery crosses the bounds of the acceptable. Oppian's abhorrence at this abuse of the natural world parallels that of Neoptolemus, who at first cannot conceive of tricking the enemy in the cowardly and shameful manner suggested by Quintus'

38 On the Wooden Horse as a $\delta$ '́ $\lambda$ os, see Od. 8.494. Detienne / Vernant (1978) 23: "Such is the 'duplicity' of mêtis which, giving itself out to be other than it is, is like those misleading objects, the powers of deception which Homer refers to as dolos: the Trojan Horse, the bed of love with its magic bonds, the fishing bait are all traps which conceal their inner deceit beneath a reassuring or seductive exterior." On the implicit analogy between fishing and warfare, see further ibid. 44. 
Calchas and Odysseus. Yet Oppian's fishermen are elsewhere masters of bait and guile (and are praised for this skill); a line can be drawn between wily, successful fishing and loathsome immorality, and this is what Neoptolemus must learn. Book 12 of the Posthomerica explicitly centres around this issue of treacherous guile, for the Trojan Horse provides an uncomfortable moral sticking-point in this war. Calchas prophesies that trickery, not force, is the way to win the war:

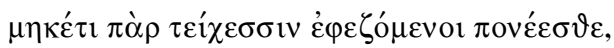

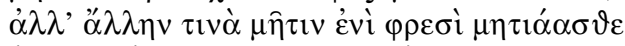

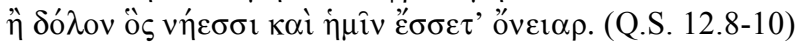

Waste no more labor on besieging the city, But rather try to devise some different device Or stratagem that can benefit us and our ships.

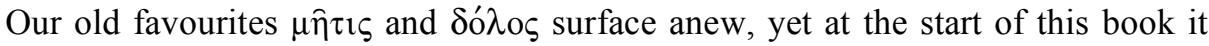
seems that Neoptolemus will be utterly unable to countenance such 'cowardly' behaviour. ${ }^{39}$ Previously so deferent to Calchas' prophecies, the young man now vehemently criticises his proposal, advocating instead a traditional, man-to-man combat:

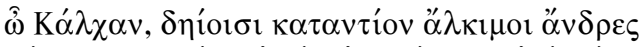

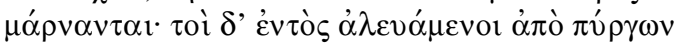

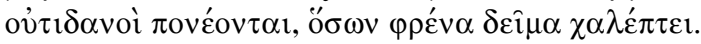

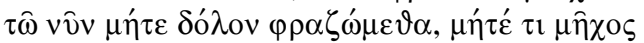

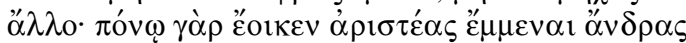

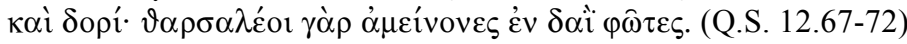
Kalchas, strong men stand and fight their foes
When they fight, while those who skulk inside and struggle
Only on their walls are the worthless victims of fear.
Let us not, then, look for a trick or any kind
Of stratagem. Work with the spear is the one true test
Of champions. Brave men always prevail in battle.

Neoptolemus, so much a neophyte that his charioteer must identify Deiphobus to him (9.224-228), has clearly misjudged the necessities of this war. Without the experience of those years of drawn-out siege which have so worn down the others, he reveals the naivety with which he approaches the combat. ${ }^{40}$ His own father has already fallen victim to just such a 'stratagem', the bow of Apollo, and

39 Cf. Campbell (1981) 24, who cites Idas (A.R. 3.555-556) and Flaminius (Sil. 5.77-78) as parallels to this 'heroic' rejection of $\delta$ ó̀

40 Philoctetes here falls into the same camp. 
Ajax's lament for the dead Achilles speaks volumes about this clash between might and guile:

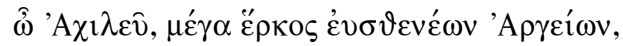

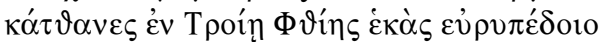

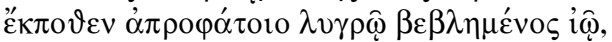

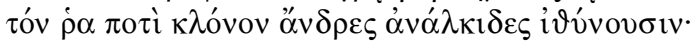

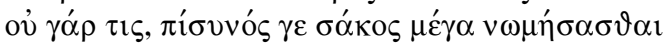

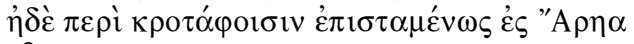

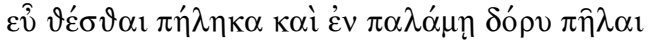

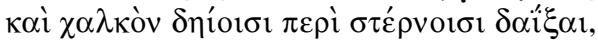

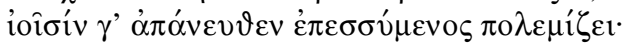

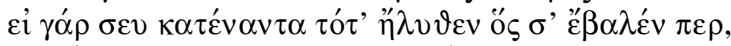

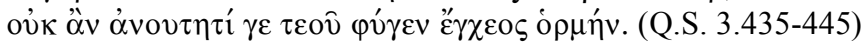

Achilles, mighty bulwark of the Argive forces,

You have died at Troy far from the plains of Phthia,

Struck down by a cursed arrow from an unknown source,

Such as are shot into the fray by feeble men.

For no one who trusts himself to handle a bulky shield,

Who has the skill to set a helmet on his temples

Properly for battle, wield a spear in his hand

And break the bronze upon the breasts of foes,

Attacks and fights with arrows from a distance.

If the man who had struck you had met you face to face,

He wouldn't have escaped your rushing spear unwounded.

Ajax's lament for the hero picks up on the cry of the dying Achilles himself, a cry

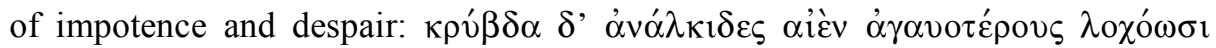
$(3.76),{ }^{41}$ and prefigures his own vitriolic outbursts against Odysseus, his disgust that the fortunes of battle are no longer decided by strength and bravery but by cowardly guile. ${ }^{42}$ In refusing to allow for the possibility of trickery, then, Neoptolemus blindly advocates his own destruction and has to be cautioned by the gods themselves (12.93-98). Neoptolemus may well be the son of Achilles, like him in both form and mind, ${ }^{43}$ but this, as we know, is something of a mixed blessing: Achilles' blind rage, his single-minded determination, may be ideal for hewing down Trojans but is apt to become troublesome in its lack of reason and perspec-

41 "Stealth is the weakling's way to snare a better man."

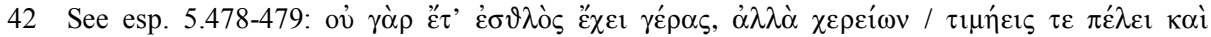

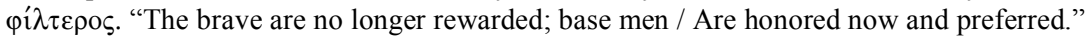

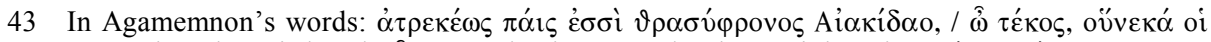

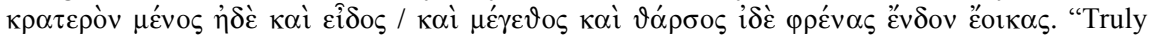
you are the son of Aiakos' dauntless grandson, / My child; you have his outstanding strength, appearance, and size, / As well as his courage and inward qualities of mind." (7.689-691; cf. 12.287-288). 
tive. This, after all, is the premise of the Iliad, and Neoptolemus would do well to analyse his role-models carefully. The death of Achilles and the victory of Odysseus over Ajax both point to a new age of guileful warfare. In the end, Neoptolemus must prove less intractable than his father; in fact, he willingly plays his part in the deception, being the first to enter the Horse (12.314-315).

In the simile of Neoptolemus as a fisherman, the trickery is effected by means of the fisherman's flame. Indeed, the whole simile is drawn in chiaroscuro tones,

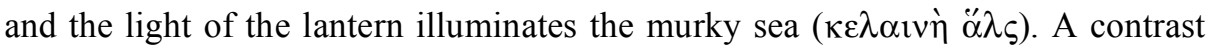
between light and darkness is already implicit in the Halieutic model, for light is the very means by which such fish are caught, yet whereas Oppian's fire is a more

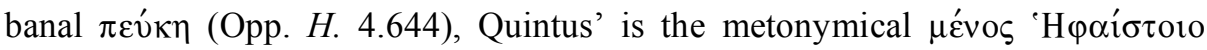
(7.570), an exhilaratingly powerful force. The lure is the force of fire, harnessed

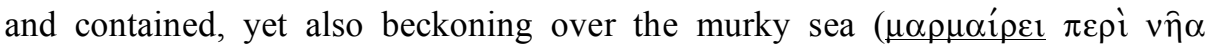

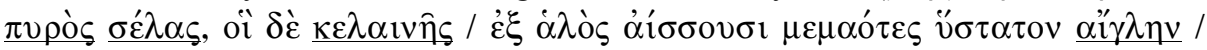

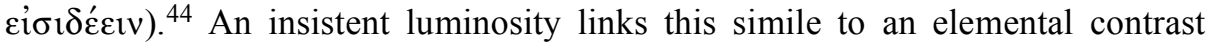
between light and darkness, fire and water. The dichotomy between light and darkness is of prime importance for Quintus; heroic figures in the poem (Memnon, Penthesileia, Achilles) are frequently associated with dazzling light or black darkness, their polarities played out on the chromatic field. ${ }^{45}$ Further, these fishes' foolish zeal is truly pathetic, and their innocent delight in the light merges all too quickly into the more ominous delight of the fisherman (7.575), their desire described in terms more commonly applied to a warrior's eagerness for battle. ${ }^{46}$ For $\alpha i \gamma \lambda \eta$ (7.573), that gleam of the fire which so attracts the fish, in epic more often signifies the flashing arms of a warrior; the attraction of war and armour is precisely that gleam of glory, the seductive brightness of the light and the prospect of competing in strength with a glorious hero. Penthesileia's armour gleams brightly upon her death (1.657-658); after Neoptolemus' arrival, the

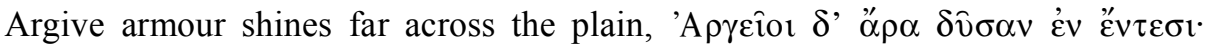

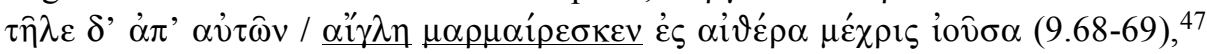

44 7.572-574: "The fire shines brightly round the boat; from the inky water / The fish come darting, eager for a glimpse of the gleam / That is their last."

45 See Goția, this volume, on books 1-2.

46 Quintus uses $\mu \alpha \dot{\omega} \omega$ over twenty times in a martial context. Similarly, the Homeric hapax $\tau \alpha v v-$ $\gamma \lambda \omega \chi_{1 \varsigma}(575)$ which here denotes the fisherman's trident is also used at Q.S. 6.463 of Podalirius' spear. Cf. Il. 8.297 and Simon. 7.443 .1 (arrows) vs. Opp. H. 5.255, 3.88 (trident).

47 "Then the Argives put on their armor, the gleam of which / Traveled so far that it lighted the sky itself." 
and a fiery glow lights Neoptolemus' breastplate when he rushes like Ares against Deiphobus (9.220-221). ${ }^{48}$ These fish desire (7.573: $\left.\mu \varepsilon \mu \alpha o ́ \tau \varepsilon \varsigma\right)$ to see the fisherman's lantern, the ${ }^{\prime} \sigma \tau \alpha \tau o \zeta \alpha$ i $\gamma \lambda \eta$, and their desire is comparable to that longing for a more metaphorical $\alpha$ i $\gamma \lambda \eta$, the warrior's desire for glory in war. This gleam is the seduction of an immediate glory, dangerous to those too close to the dazzling force; it takes the distance of a fisherman or god to perceive the fire and the trident behind the gleaming light. ${ }^{49}$ These fishes' desire, then, is vain and misplaced, and their quest for $\alpha{ }^{\prime} \gamma \lambda \eta$ brings not light and glory but death and darkness; not their hearts but that of their conqueror is "brightened" by the catch

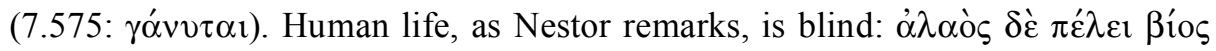
$\dot{\alpha} \nu \vartheta \rho \omega ́ \pi 01 \sigma \imath(7.79)$; appearances are deceptive, and rationality must take control of animal emotion. ${ }^{50}$ Quintus' analogy raises questions about the desire for war: when do zeal, courage and glory become blind stupidity or frenzied blood-lust? We cannot forget the warning of Ajax, whose tale is played out at length in book 5. This is a man whose desire for glory and recognition eclipses his perceptive faculties, whose senses are clouded in frenzy. ${ }^{51}$ Just as the fish perish needlessly through their own excess of emotion, so Ajax dies by his own hand. Each is a tale of limited vision and misplaced fervour.

The simile further takes its place within a nexus of interconnected fire images in the epic. For whilst it depicts a controlled, productive fire of craftsmanship (here, the fisherman's $\tau \dot{\varepsilon} \chi \nu \eta$ ), the simile's fire also echoes the metaphorical fires of the hero's $\mu$ '́vo ${ }^{\prime}$ and prefigures the blazing fires which spell the end of Troy. The torch on the fisherman's boat is the force of Hephaestus subject to a regulatory $\tau^{\prime} \chi \vee \eta$ : a small, deliberate fire allows the fisherman to impose his will upon the

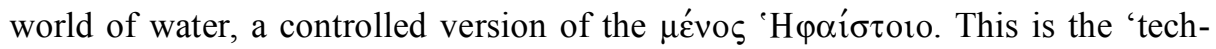
nical' Hephaestus, the power of the craftsman who created Achilles' magnificent

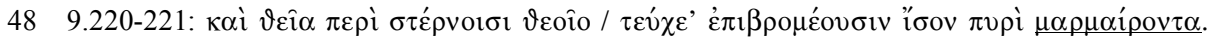
"The heavenly armor that covers the breast / Of the god resounds and flashes as brightly as fire."

49 A trope echoed and reversed in Quintus' aetiological tales of Niobe's rock (1.299-304) and Selene's grey spring (10.134-136), whose true composition is revealed only to those near at hand.

50 This too is the cornerstone of Oppian's moralising, for throughout the Halieutica it is through their excessive desires (for food, sex or death, or through a misplaced sense of comradeship) that fish are caught. The fisherman, with all his intelligence, art and $\tau \dot{\varepsilon} \chi v \eta$, directs the bigger picture, in contrast to his victims' frenzied emotion. Toohey (1996) 202-205, though he overstates the case, reads an opposition between $\tau^{\prime} \chi \chi \nu \eta$ and $\lambda \dot{v} \sigma \sigma \alpha$ as the structuring polarity behind the Halieutica as a whole. On the fruitful link between didacticism and Quintus' gnomai, see Maciver, this volume, esp. p. 264: "Quintus is being didactic about an ethic."

51 This clouding reaches its climax when Ajax mistakes animals (the flock of sheep) for men (Odysseus and his comrades) at 5.404-412. The all-too-easy slippage between man and beast continues. 
armour. ${ }^{52}$ At 571 the fisherman's breath ( $\left.\dot{\alpha} \ddot{v} \tau \mu \eta^{\prime}\right)$ kindles his fire, a word which places the simile firmly in Hephaestus' realm, for $\alpha \ddot{\nu} \tau \mu \eta^{\prime}$ is used both to denote bellows (indeed, those very bellows with which Hephaestus made the arms Neoptolemus now wears), ${ }^{53}$ and figuratively for the 'breath' of fire itself. ${ }^{54}$ In the Odyssey the $\alpha \ddot{v} \tau \mu \eta$ (here "fiery heat") of the stake burns Polyphemus' eye (Od. 9.389), and the resultant sound recalls the hiss of a blacksmith's axe tempered in water (9.391-394). Water lessens the ferocious heat of fire and renders it productive; it is the balance of these forces which creates a mighty weapon ( $\tau$ ò $\gamma \grave{\alpha} \rho \alpha \hat{v} \tau \varepsilon$

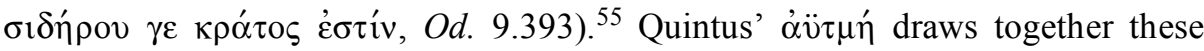
associations: a balance of fire and water, the power of fire and of Hephaestus, the controlled art of the blacksmith.

Even more in this epic, however, fire comes to denote a battle-lust of furious proportions. ${ }^{56}$ In the Iliad Achilles was the fiery hero par excellence - "swift, short-lived, and dangerous", 57 and at the start of the Posthomerica countless Trojans fall before the wrath of Achilles and Ajax like trees blazing in a forest fire (1.536-537). Yet in the Posthomerica it is Ajax who is increasingly figured in the imagery of fire. Ajax's fiery force keys into a whole set of Homeric similes which denote fire and $\mu \varepsilon^{\prime} v \varsigma_{\text {, for }}$ once Achilles has been literally engulfed in flames it is Ajax whose spirit is enflamed, and who is notoriously ardent and impetuous, whose angry heart boils like a cauldron $\left(5.380: \lambda \varepsilon^{\prime} \beta \eta \varsigma\right)$ or a forest fire

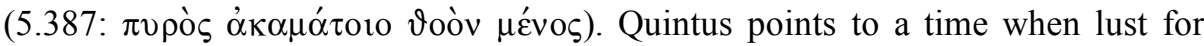
battle has gone too far: $\mu \varepsilon^{\prime} v \varsigma_{\varsigma}$ is a vital force, a strength, vitality and prowess in combat, ${ }^{58}$ yet it can all too swiftly merge into blind rage or $\lambda \hat{v} \sigma \sigma \alpha(5.405$, 5.466). ${ }^{59}$ Frenzy and excessive passion cannot win this war; throughout this epic emotions run to deadly excess, and those who leap headlong into light and glory are doomed to be destroyed. Consulting Nestor once again, we are shown that

52 Note that we have been reminded only a hundred lines before (7.447) of Hephaestus' role in producing this armour, the armour which Neoptolemus now wears.

53 Il. 18.471.

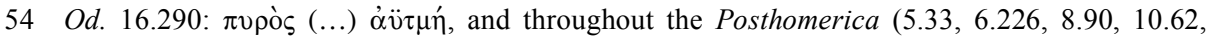
12.503).

55 Cf. Redfield (21994) 172, who notes the connection between iron and the $\mu \varepsilon ́ v \circ \varsigma$ of fire.

56 Cf. Whitman (1958) 130, on Iliad 11: "By this point in the poem, [...] anger and fire are inseparably associated."

57 Whitman (1958) 138. Achilles is in the Iliad increasingly figured in terms of fire, which becomes a symbol for the incandescent hero. Mackie (1998) 332: "it may be said that Achilles has a special association with fire in early epic, one that helps distinguish him form the other Achaean warriors at Troy." Achilles is on more than one occasion immersed in fire, as a child and in the $\mu \alpha \chi \chi \eta \pi \alpha \rho \alpha \pi \circ \tau \alpha \alpha_{\mu 1 o}$, the battle by the Scamander in Il. 21.

58 For Rose (1969) 400, $\mu$ ćvo is best summed up as "fighting spirit". As Redfield $\left({ }^{2} 1994\right) 172$ puts it: "Fire has a menos. Or we could better say that menos is fire; menos is energy [...]"

59 Redfield ( $\left.{ }^{2} 1994\right)$ 202: "The lussa is the heat of menos raised to a pitch of fever." 
grief and anger should be channelled into more productive ends: too much emotion emasculates, and burdens are to be borne with stoicism. ${ }^{60}$

\section{IV}

If fire is that internal force which brings a warrior to life but which threatens to destroy him, Neoptolemus, in the fisherman simile a temporary master of fire, must watch that he too is not burned. Whereas the oi $\gamma \lambda \eta$ of the fisherman's fire spells death for the fish, another $\alpha$ i $\gamma \lambda \eta$ at the end of the epic signals a more profoundly destructive fire: the " $\alpha \sigma \varepsilon \varepsilon \tau \circ \varsigma \alpha i \gamma \lambda \eta$ which ravages Troy (13.478). As in the Iliad, doom for the Trojans is encapsulated in a vision of the burning city. Flames simultaneously enact and represent the annihilation of Troy, and this fire stands as an end-point or literalisation of those psychic fires which burn throughout the epic. ${ }^{61}$ Fire brings destruction, whether in the flames breathed by the Erinyes (5.33), in the threat that Troy or the Argive ships will burn, or in those funeral pyres which swallow the dead and destroy the living. ${ }^{62}$ At the end of the Posthomerica, Trojans burn in their city like animals caught in a forest fire (13.487-493). Entrapped and powerless, they can only wait to be destroyed by the blazing force (492: ßín) of the fire-god. This is the fire of war, a symbol of Troy's

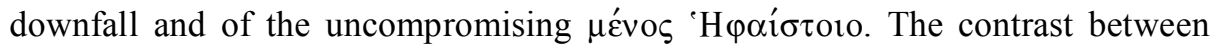
fire and water is thus mapped onto that between Trojans and Achaeans. Whilst fire signifies the end of Troy, it is water which endangers the Greek forces, for in book 14 Quintus switches focus from blazing fire to uncontrollable seas, to the Achaean ships tempest toss' ${ }^{63}$

The fisherman simile of 7.569-575, itself a vision of fire and water productively harnessed by the fisherman, is followed by the depiction of Neoptolemus as a torrent impervious to fire:

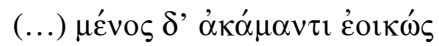

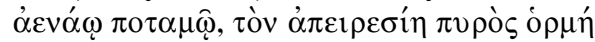

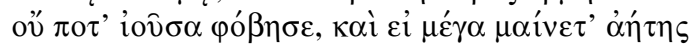

'H

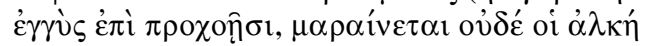

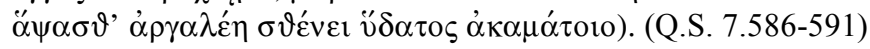

60 Q.S. 7.38-55; cf. Phoenix at 7.661-663.

61 Cf. Mackie (1998) 335, of Hephaestus' fire in Il. 21: "The fire might be seen as an externalization of the fury that characterizes Achilles' return to the field of battle."

62 The pyres, for instance, of Penthesileia, Achilles, Paris and Oenone. Note too that the epic begins with the funeral pyre ( $\pi \nu \rho \eta$ ) of Hector (1.2). See Bär, this volume, p. 34.

63 For the finality of book 14 see Carvounis, this volume. 
(...) His strength was equal to that of a river

That never fails, which the onset of an enormous fire

Can't put to flight, not even with a raging wind

To stir the fire god's sacred strength, for if it approaches

Those flowing waters the fearful force of it

590

Is quenched and cannot touch the tireless tide.

The $\mu \varepsilon^{\prime} v \varsigma$ of the river and the $\mu \varepsilon^{\prime} v o \varsigma$ of Hephaestus stand starkly opposed, evok-

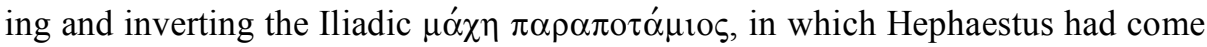
to Achilles' aid against the river-god Scamander. There Scamander had been defeated, halted by Hephaestus' flames and made to promise not to defer the fiery destruction of Troy; ${ }^{64}$ here the symmetry is restored when the force of Hephaestus cannot prevail over the river. This elemental clash continues when in book 9 of the Posthomerica Neoptolemus once again takes the role of water, this time in opposition to Deiphobus' fire. The first half of book 9, before the arrival of Philoctetes, is structured around a series of parallels between the Greek and Trojan camps, and more specifically between Neoptolemus and Deiphobus. The latter, emboldened by the absence of Achilles, wreaks havoc amongst the Greeks until he is observed by Neoptolemus, who faces him with wrath. Deiphobus, awed by the son of Achilles, wavers in front of Neoptolemus like a fire before water:

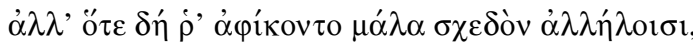

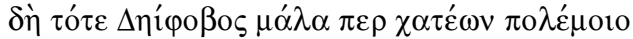

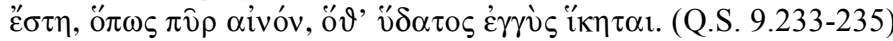

When at last the two drew very close to each other,

Deiphobos, despite his great desire for battle,

Stood still like the dreadful fire that reaches water's edge.

Deiphobus, he whom Achilles had previously terrified (9.227-228), now quakes once more, this time at Neoptolemus' astonishing strength and likeness to his father (9.236-238). As we have noted, this is a likeness emphasised throughout the epic, but particularly in book 7 and in the first half of book $9 .^{65}$ The focus on an absent Achilles once again draws attention to the vital role of Neoptolemus in this post-Achillean world and reflects metapoetically upon the influence of Homer's absent presence, here evoked in the inverted $\mu \alpha \chi \chi \eta \pi \alpha \rho \alpha \pi \mathrm{\alpha} \tau \dot{\alpha} \mu{ }_{10}{ }^{66}{ }^{66}$

64 See esp. Il. 21.373-376. Whitman (1982) 82: “The surrender of the river-god before the flames of Hephaestus is the real foretoken of the city's fall."

65 See e.g. Neoptolemus at Achilles' grave (9.46-60), or the speeches of Antenor (esp. 9.9-13) and Deiphobus (esp. 9.97-99).

66 Cf. Schmitz, this volume, p. 76. 
Such inversion comes to the fore with the second of Quintus' fisherman similes, an image which links Deiphobus both to Achilles and to Neoptolemus:

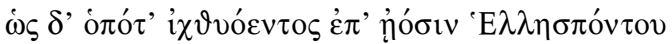

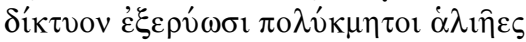

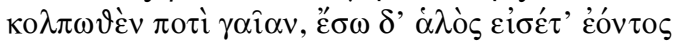

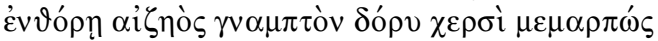

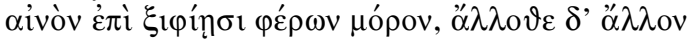

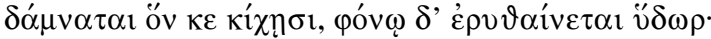

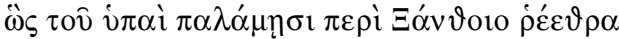

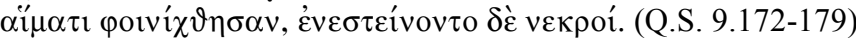
As on the shores of the fish-abounding Hellespont
Hardworking fishermen pull a bulging net
Up onto the land, and while it is still in the sea
A young man jumps in with a barbed harpoon in his hand
To deal a dreadful doom to the swordfish, on all sides
Killing any he catches and reddening the water with blood;
So by Deiphobos' hands the Xanthos' flowing water
Was crimsoned with the blood of the corpses that crowded there.

Whilst the motif of fishing links Deiphobus and Neoptolemus within the Posthomerica, the weight of literary tradition takes us back to Homer, for Quintus' Deiphobus assumes the role played by Achilles in the Iliadic $\mu \alpha \alpha \chi$ $\pi \alpha \rho \alpha \pi \circ \tau \alpha \dot{\mu} \mu \iota \varsigma$, reddening the Scamander with blood. At the start of Iliad 21, Achilles had filled the river with the bloody corpses, his victims tumbling and drowning like locusts seeking refuge from a fire (Il. 21.12-14), fleeing from Achilles like fish from a mighty dolphin (Il. 21.22-24). Quintus elsewhere uses a similar dolphin simile to depict Ajax's frightened opponents; ${ }^{67}$ here, the simile of Deiphobus as a fisherman forms a counterpart to the Iliadic locust simile. Quintus' simile, however, is twice as long and much more detailed than either the locusts or the dolphin of Iliad 21, and its details are drawn from a passage in the Halieutica on swordfish. ${ }^{68}$ In book 3 of the Halieutica, Oppian had related the three ways to catch a swordfish: in the first method, a hook is placed without trickery on a baited line; the impetuous swordfish attacks and is caught (Opp. $H$. 3.529-541) ${ }^{69}$ The swordfish, caught up in its own foolish aggression, needs no trickery to be caught. The downfall of Oppian's swordfish is precipitated by the

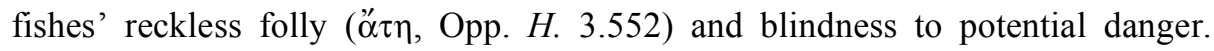

67 At 3.270-272, of Ajax warding off Lycians and Trojans from the body of Achilles.

68 Cf. James (2004) 316 n. 167-179.

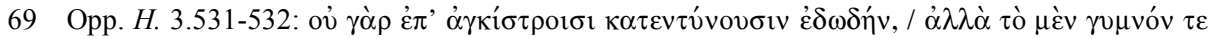

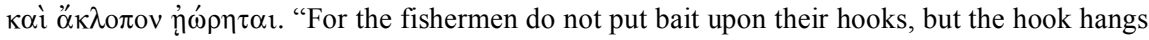
from the line naked and without deceit." 
A second method we have already marked in Quintus' simile: a swordfish is caught in the fisherman's nets and killed, doomed by its own stupidity:

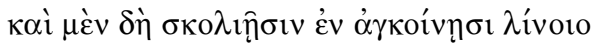

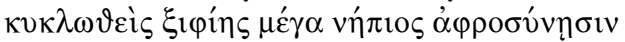

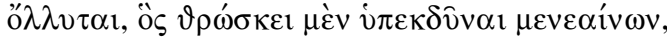

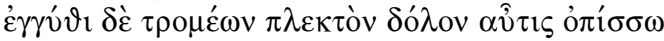
570

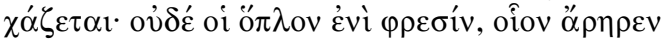

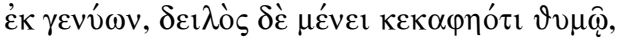

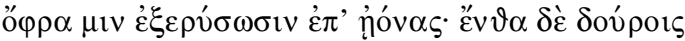

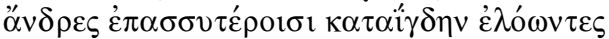

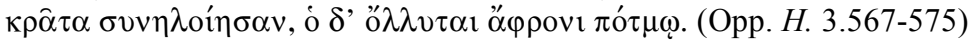

\begin{abstract}
Moreover, when encircled in the crooked arms of the net the greatly stupid Swordfish perishes by his own folly. He leaps in his desire to escape but near at hand he is afraid of the plaited snare and shrinks back again; there is no weapon in his wits such as is set in his jaws, and like a coward he remains aghast till they hale him forth upon the beach, where with downward-sweeping blow of many spears men crush his head, and he perishes by a foolish doom.
\end{abstract}

The fishing simile which characterised Quintus' Neoptolemus (Q.S. 7.569-575) was based around the subtle deception of a night-fisherman who lures in fish with a light; that of Deiphobus, by contrast, focuses not on trickery but on the young man's violent strength. Swordfish are entangled in the fisherman's nets and are dispatched by a youth with a blunt brutality; the river runs red with blood. Nor, I think, is this contrast mere coincidence. Just as Achilles' obsessive battle-lust almost costs him his life when Scamander finally turns upon him, so Deiphobus' bloody destruction almost costs him his, for Neoptolemus, noting his attack, would have killed him on the spot had Apollo not intervened. Book 9 depicts a bloody and fruitless battle in which Greeks and Trojans are destroyed in equal measure (see e.g. 9.145-148); the fortunes of the battle waver irresolute, neither Neoptolemus nor Deiphobus is killed, and we wait helplessly for the envoy to be sent to Philoctetes. Force leads only to further bloodshed.

This contrast between craft and bloody violence is all the stronger, moreover, when we note that Oppian's final method of killing a swordfish is rather different from the stark brutality deployed by Deiphobus. Oppian shows us an approach typical of the fisherman's devious skill: the fishermen affix a spike to a boat so that it resembles a swordfish; the fish, mistaking the boat for another swordfish and failing to see the men crouching within, are lulled into indolence, whereupon the fisherman strikes with his trident (Opp. H. 3.547-566). Oppian compares this stratagem of disguise to that of soldiers who dress in the armour of the enemy in order to infiltrate their city: 


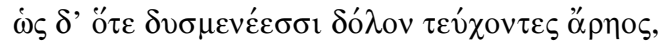

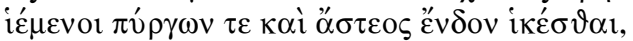

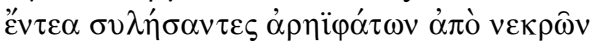

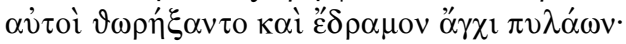
oi $\delta$ '

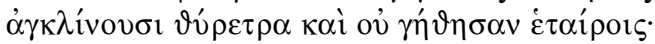

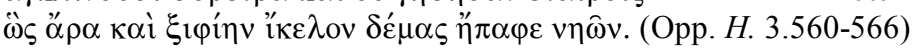

As when men devising a trick of war against their foes, being eager to come within their towers and city, strip the armour from the bodies of the slain and arm themselves therewith and rush nigh the gates; and the others fling open their gates as for their own townsmen in their haste, and have no joy of their friends; even so do boats in their own likeness deceive the swordfish.

This imagery, one of a series of martial similes in the Halieutica, is, as Bartley notes, highly reminiscent of the Trojan Horse conceit. ${ }^{70}$ The connection between the two is heightened when Quintus himself later likens the Trojan Horse to a mighty ship, pulled on its rollers across the sand (12.428-432). Men may hide in the hollow belly of both ships and Horse, and it is perhaps for this reason that

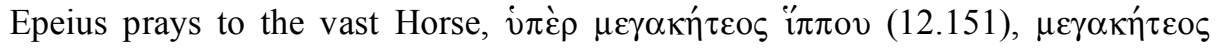
being an adjective usually reserved for ships or sea-creatures. ${ }^{71}$ The link between ship and horse, moreover, gained credence in antiquity with the rationalising notion that the Trojan Horse was originally itself a ship. ${ }^{72}$ With the Trojan Horse in the background, and with Quintus once again drawing his piscatorial imagery from a scene in the Halieutica which reflects upon martial dissimulation, it is important that unlike Neoptolemus, Deiphobus does not catch his fish with trickery, but rather with a brute force (observe too that not he, but the other fishermen, have entrapped these fish in the nets). Quintus uses the simile to contrast the bloody futility of Deiphobus' slaughter with the wily behaviour of Neoptolemus. The way to win the city of Troy, we are told time and again, is with stratagem and guile.

70 Bartley (2003) 233.

71 In fact, $\mu \varepsilon \gamma \alpha \kappa \eta \dot{\eta} \tau \varepsilon \alpha$ are almost exclusively to be found in marine contexts. Thus the five occurrences in Homer (Il. 8.222, 11.5, 11.600, 21.22; Od. 3.158), as well as those in Apollonius (4.318), Dionysius the Periegete (1087) and Oppian (1.254, 3.132, 3.546). Significantly, the last

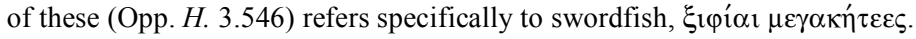

72 See Austin (1964) 34-35, van Leeuwen (1901) 129-130, Bethe (1927) 36 n. 5. I should like to thank Prof. Philip Hardie for suggesting this parallel to me. For a further connection with Oppian, note Eust. 3.261.18-26. 
In this inverted $\mu \alpha \alpha^{\prime} \eta \pi \alpha \rho \alpha \pi \circ \tau \alpha \dot{\mu} \mu \varsigma$, then, Deiphobus essays to fill the gap left by Achilles. This is the continual pattern of the Posthomerica, as one hero after another rises and falls, as both Greeks and Trojans face the question of what to do when a great leader dies. Hector and now Achilles are dead: who, asks Quintus, can fill the breach? If Penthesileia, Memnon, Eurypylus and Deiphobus rise and fall in turn, if Ajax fails and even Neoptolemus cannot succeed alone, then how can this endless cycle of repetitive, transient heroism be broken? Deiphobus is strong and brutal, but such qualities are no longer sufficient to win this war. Blood-lust and the warrior's fiery $\mu$ ćvo $\varsigma$ can only lead to escalating violence, to further fruitless slaughter, and to the kind of grim strife we see in the initial indecisiveness of book 9. Instead, the Trojan War must be ended with bold deception and a combination of guile, strength and wisdom. Neoptolemus emerges in this epic as a figure of prime importance, a new hero standing in the lee of his mighty Homeric father, a symbol perhaps for Quintus' own work. Yet Neoptolemus stands apart from his father. Unable to rival Achilles or to conquer the Trojans with strength alone, the young man finally turns to $\delta$ ó $\lambda \mathrm{o}$, to the kind of Odyssean trickery which at first seems so abhorrent to him. As the deaths of Ajax and Achilles show, a blind faith in Bín and its concomitant fiery powers can no longer suffice. Neoptolemus' distrust of 'cowardly' $\delta$ ó $\lambda$ o $\varsigma$ emerges less as virtue than as sheer naivety, and he must eventually reconcile himself to that very

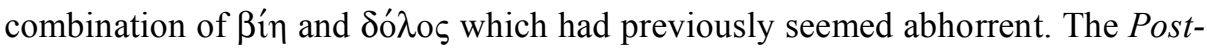

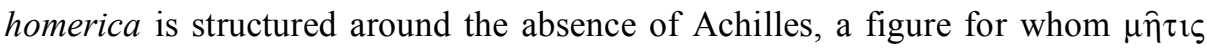
played no part, in whom a fiery rage had burned; in a post-Homeric, postAchillean world, Achaean hope now lies in the great hero's son. Foregrounding this debate through the similes of Neoptolemus and Deiphobus as fishermen, Quintus draws upon an Oppianic discourse of piscatorial and martial trickery to evoke the stratagem of the Trojan Horse. The paradigm of the fisherman's duplicity is transported to the martial sphere: only when force is married to craft, when emotion is diverted to productive ends, can the war at last be ended. 
